\title{
Normal Appendix in the Elective Inguinal Hernia Repair: \\ Case Report and Review of Literature
}

\section{Apêndice Normal numa Hernioplastia Eletiva: Caso Clínico e Revisão da Literatura}

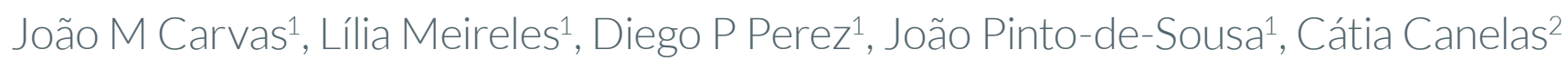

Corresponding Author/Autor Correspondente:

João Miguel Carvas [jmcarvas@gmail.com]

Av. Abade de Baçal, 5301-852 Bragança, Portugal

ORCID iD: 0000-0002-0929-2180

\begin{abstract}
INTRODUCTION: The presence of the vermiform appendix in an inguinal hernial sac is known as an Amyand's hernia. In the elective hernia repair, this represents a rare finding and the decision to perform appendectomy is always ambiguous. The literature seems to claim the idea that a normal appendix should be preserved unless the benefits of an appendectomy outweigh the risks of a future acute appendicitis.

Our purpose was to analyse all published clinical cases of Amyand's hernia indexed in MEDLINE and evaluate patient's characteristics and the surgeons' decisions regarding prophylactic appendectomy in these cases.

METHODS: A bibliographic search of MEDLINE database using "Amyand's Hernia" as keywords was done. Inclusion criteria included clinical cases in adults, where a normal, non-inflamed appendix was encountered during elective hernia repair. We also present the clinical case from our institution.

RESULTS: We identified 25 papers from which 41 clinical cases were extracted. In more than half the clinical cases the surgeons opted for a prophylactic appendectomy. This decision seemed to have no impact on the type of hernia repair (with/without mesh) or on the reported complications.

CONCLUSION: Amyand's hernia is a rare finding, and even though prophylactic appendectomy is not recommended, most of the surgeons in the published clinical cases opted to do so. The absence of evidence-based information and the very low risk associated with appendectomy in this context may explain this option. The final decision therefore remains surgeon-dependent.
\end{abstract}

KEYWORDS: Appendectomy; Appendix; Elective Surgical Procedures; Hernia, Inguinal 


\section{RESUMO}

INTRODUÇÃO: A presença do apêndice ileocecal num saco herniário inguinal é conhecida como hérnia de Amyand. Na hernioplastia eletiva, representa um achado raro e a decisão de fazer uma apendicectomia é sempre ambígua. A literatura parece apontar para a ideia de que um apêndice normal deve ser preservado a não ser que os benefícios de uma apendicectomia superem os riscos de uma apendicite aguda no futuro.

O nosso objetivo foi analisar todos os casos clínicos publicados de hérnia de Amyand indexados na MEDLINE e avaliar as características dos pacientes e as decisões dos cirurgiões quanto à apendicectomia profilática nestes casos.

MÉTODOS: Foi efetuada uma pesquisa bibliográfica na MEDLINE usando os termos "Amyand's hernia" como palavras-chave. Os critérios de inclusão foram casos clínicos em adultos, em que foi encontrado um apêndice ileocecal normal, não inflamado durante uma hernioplastia eletiva. Apresentamos também um caso clínico da nossa instituição.

RESULTADOS: Foram identificadas 25 referências de onde foram extraídos 41 casos clínicos. Em mais de metade dos casos clínicos os cirurgiões optaram pela apendicectomia profilática. A decisão não mostrou ter impacto no tipo de hernioplastia (com ou sem prótese) ou nas complicações reportadas.

CONCLUSÃO: A hérnia de Amyand é um achado raro, apesar de não recomendada, a apendicectomia profilática foi realizada maioritariamente nos casos clínicos publicados. A ausência de informação baseada em evidência e o baixo risco associado à apendicectomia neste contexto podem explicar esta opção. A decisão final assim, permanece dependente do cirurgião.

PALAVRAS-CHAVE: Apêndice; Apendicectomia; Hérnia Inguinal; Procedimentos Cirúrgicos Eletivos

TABLE 1. Classification system for Amyand's hernia and proposed management (adapted), by Losanoff and Basson.

\begin{tabular}{|c|c|c|c|}
\hline Type of Amyand Hernia & Hernia Contents & Appendix Management & Hernia Management \\
\hline Type 1 & Normal or minimally inflamed appendix & Reduction / Appendectomy & Mesh hernioplasty \\
\hline Type 2 & Acute appendicitis & Appendectomy through hernia & Acute appendicitis, peritonitis \\
\hline Type 3 & $\begin{array}{c}\text { Acute appendicitis, } \\
\text { other abdominal pathology }\end{array}$ & $\begin{array}{c}\text { Appendectomy, other } \\
\text { procedures as appropriate }\end{array}$ & Non-mesh hernioplasty \\
\hline Type 4 & & &
\end{tabular}

\section{INTRODUCTION}

Amyand's hernia represents the projection of the vermiform appendix within an inguinal hernia sac becoming incarcerated in it. This rare finding is named after Claudius Amyand, a French surgeon that in 1735 performed the first appendectomy through the groin region of an 11-year-old child who presented a fistula caused by a perforated appendix (ingested pin) in the hernia sac. ${ }^{1,2}$

The incidence of an Amyand's hernia ranges between $0.4 \%$ to $0.6 \%$ of adult inguinal hernias and $1 \%$ of children hernias. Acute appendicitis in an Amyand's hernia is even rarer representing $0.1 \%$ of all acute appendicitis. ${ }^{3,4}$ The diagnosis of an Amyand's hernia is often incidental during surgery. History, physical examination or lab results are not helpful in the differential diagnosis. Cross-sectional imaging in the elective hernia repair is not generally available and even in the emergency scenario ultrasonography or computed tomography (CT) scan are often non-diagnostic. ${ }^{5}$

In Amyand's hernia, the incarcerated appendix can be either completely normal or present inflammatory signs. Strangulation may lead to perforation and/or gangrene and local complication which include orchitis, abdominal wall abscess and necrotizing fasciitis. ${ }^{6}$ Sepsis and death may follow due to peritoneal spread of the infection. ${ }^{4}$ It is not clear if patients with an undiagnosed Amyand's hernia are more susceptible to acute appendicitis. Some authors claim this is the case, and, indeed, it seems that ischemic events in the inguinal canal can lead to secondary appendicitis.?

Accordingly, to the classification proposed by Losanoff and Basson in $2007^{8}$ Amyand's hernias can be divided in four types, each of them linked to a specific management protocol (Table 1). (1) Amyand's hernia with a normal-appearing appendix in the sac, (2) Amyand's hernia with inflamed appendix, (3) Amyand's hernia with a perforated vermiform appendix, and (4) complicated with intra-abdominal pathology like malignancy. ${ }^{8}$ Other classifications also include incisional hernias. ${ }^{9}$

Complicated Amyand's hernias (type 2-4) are best treated by appendectomy although malignancy poses specific challenges that are out of the scope of this review. For type 1 hernias there is still some debate on whether prophylactic appendectomy should be performed. Most authors seem to advise that a normal appendix should be reduced back to the abdominal cavity thus avoiding the contamination of a previously clean surgical field. 9.10 Another concern is that appendectomy may require the enlargement of the surgical incision increasing the re- 
currence risk. ${ }^{11}$ Other authors defend universal appendectomy to avoid future hernia recurrences or appendicitis. ${ }^{12}$ The use of a synthetic mesh in the hernia defect at the time appendectomy is performed is also a point of debate, especially in cases of perforated appendicitis.

Although there seems to be a consensus in the literature to avoid appendectomies in type 1 Amyand's hernias, it is not known the actual prevalence of appendectomies in these hernias. We therefore aim to look at the published clinical cases and evaluate the surgeon attitude towards the normal appendix. We also present a clinical case in our institution.

\section{METHODS}

A bibliographic search of MEDLINE database, using the terms "Amyand's" AND "hernia, inguinal" [MeSH] was conducted on August 22, 2018. Two hundred published scientific papers on this subject spanning more than thirty years were identified. Reports focusing on the paediatric population ( $n=39$ ), reports where an inflamed appendix was identified ( $n=93$ ) or reports where information was not retrievable (unavailable full text, review without clinical cases, published in a language other than English, French, Spanish or Portuguese) ( $n=43)$ were excluded. At the end collected data from 25 published papers reporting 41 cases were identified (Fig. 1).

Herein the case of an Amyand's hernia is presented and also aimed to evaluate the attitude of the surgeons towards appendectomy in the published cases.

\section{STATISTICAL ANALYSIS}

Categorical variables are presented as frequencies and percentages, and continuous variables as means and standard deviations. Normal distribution was checked using Shapiro-Wilk test or skewness and kurtosis. Statistical analysis was performed with Student's t-tests for unpaired observations. A two tailed $p$-value smaller than 0.05 is considered statistically significant. Statistical analysis was performed with SPSS 18.0 program.

\section{CASE REPORT}

A 72-year-old male patient was referred by his assistant physician for a long standing right inguinal hernia with several years of evolution. The physical examination showed a bulge in the right inguinal region that increased with Valsalva maneuvers and the overlying skin presented no inflammatory signs. There is also no previous history of hernia surgery or previous episodes of incarceration or strangulation. Following diagnosis, the patient was offered surgical repair, in day surgery regimen, which was scheduled for two months after. An oblique incision over the right inguinal region was used to access the inguinal canal. There was a bulge of the posterior inguinal wall compatible with a direct inguinal
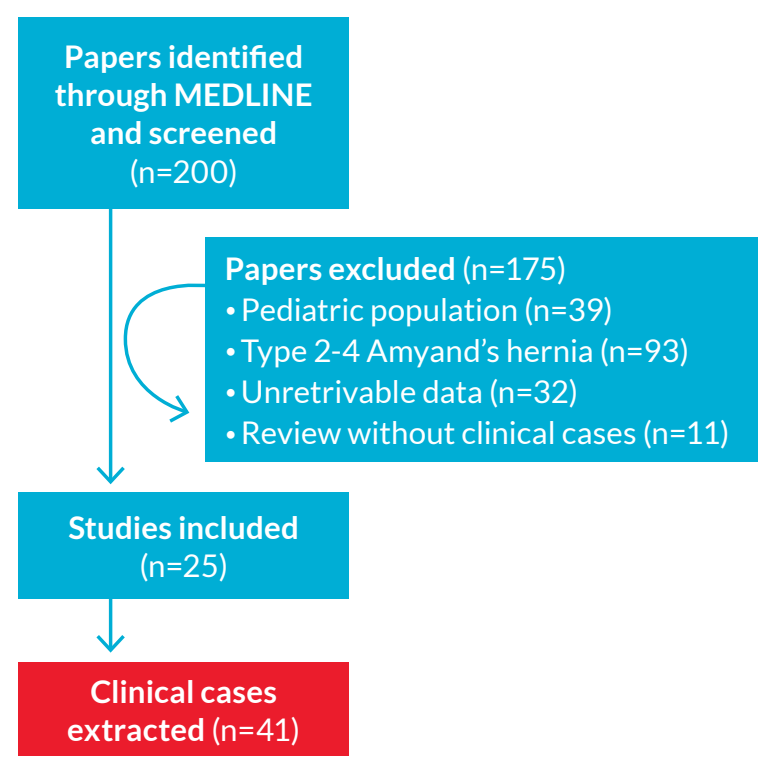

FIGURE 1. Flow diagram of case selection.

hernia. After the spermatic cord was isolated an indirect inguinal sac was also found. The sac contained a tubular structure, about 6-7 cm long, with no signs of inflammation or perforation, which was compatible with a vermiform appendix (Fig. 2). At that time, even facing with a normal appendix, a prophylactic appendectomy was performed, protecting the incision borders. The hernia sac was then sutured, and the hernia was corrected with a Lichtenstein polypropylene mesh hernioplasty.

The patient was discharged that same day without any immediate complication. No complications or recurrence was identified in the follow-up consults. Pathology results revealed a normal appendix.

\section{RESULTS}

Data was extracted from 41 clinical cases of Amyand's hernia. All patients were male in this series of clinical cases. The mean age of patients was 49 years $(S D=17.1$; range: $19-81$ ). Appendectomy was performed in 22 cases (53\%) and these patients were younger in average (45.1 years) when compared with the non-appendectomy group (53.7 years). This difference did not reach statistical significance $(p=0.108)$

Thirty-three cases (80\%) where right sided hernia and eight cases (20\%) were left sided. Ten cases consisted of indirect inguinal hernias while five were direct inguinal hernias. In 26 cases no classification of the inguinal hernia existed.

Mesh hernioplasty was performed in 35 cases in total (85\%). In the appendectomy group, 19 of the 22 patients had a mesh hernioplasty (86\%). In the remaining cases a tissue-based surgery (non-mesh) was performed. Regarding the surgical approach the majority of authors reported open hernia repairs. One report described a laparoscopic approach in three clinical cases and they 
performed mesh hernioplasty without appendectomy in all of the patients. ${ }^{22}$ Intraoperative findings in these cases revealed the presence of the vermiform appendix in 30 cases, sometimes accompanied by the cecum in nine cases and a small bowel loop in two cases. Twenty-eight appendices were described as normal, while four had slight oedema, and three presented adherences to the hernia sac. Moderate edema or adherences were accepted for inclusion in this review. Only four papers presented the final pathology result.

The mean of length of hospital stay was 2.7 days (SD: 2.1; range: 0-6). No recurrence data or morbidity or mortality was reported.

\section{DISCUSSION}

In our review of type 1 Amyand's hernia, surgeons opted for appendectomy in 53\% of cases. This is a significant figure, considering that only a small minority of published authors defend universal appendectomy independently of the type of Amyand's hernia. ${ }^{13}$ One of the arguments to avoid appendectomy in these cases is the possible contamination of a clean surgical field. In this review no complications, including infections of the surgical site, were reported in any of the appendectomy cases. Even though this could represent a publication bias, favouring submission of cases where a positive surgical decision is made (appendectomy) there are some larger series of cases that show higher percentages of appendectomies when considering all the cases from that institution. ${ }^{14,15}$

In $86 \%$ of the patients submitted to appendectomy a mesh hernioplasty was performed. The use of mesh decreases recurrence rates of inguinal hernias and is the gold standard even for Amyand's hernia with or without appendectomy. ${ }^{14}$ It is not recommended in the case of complicated appendicitis, but some authors reported mesh hernioplasty even for type 2-4 Amyand's hernia. ${ }^{16}$

In the present case the senior surgeon decided to perform appendectomy. The decision seemed to be logical given the very low risk of infection. In this patient the appendix base was immediately visible and accessible allowing for a safe surgery, and therefore there was no need to enlarge the incision of further tissue dissection. Some authors claim that the need to increase incision length and tissue handling in these cases increases the probability of hernia recurrence. ${ }^{11}$ On the other hand the risk for a recurrence of the hernia with a re-herniation of the appendix seemed significant. This possibility, in a surgically modified inguinal canal, posed the risk of a serious complication with a difficult diagnosis.

Most of Amyand's hernia occurs in the right inguinal canal mainly due to anatomical proximity reasons. Left Amyand's hernias have also been reported and are generally explained by (1) a long vermiform appendix that crosses the midline; (2) a floppy or mobile cecum; (3), a

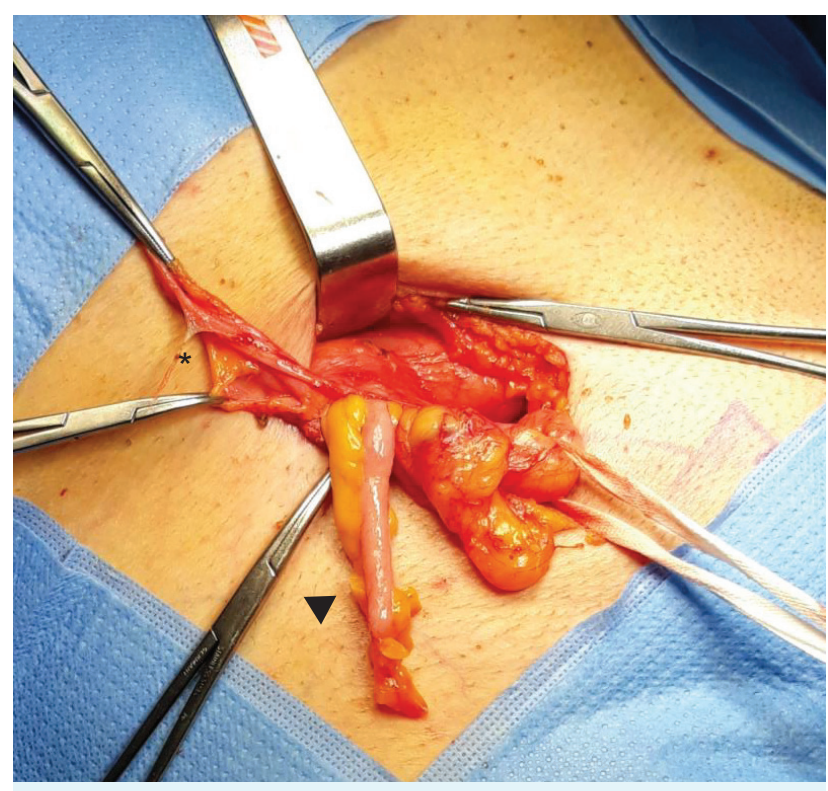

FIGURE 1. Image of a normal vermiform appendix without signs of inflammation after opening of an indirect inguinal sac. Vermiform appendix (arrow head) and Hernia sac (asterisk).

situs inversus; (4) and an intestinal malrotation. The risk of an atypical appendicitis in these patients makes appendectomy mandatory in left Amyand's hernia. In our review left Amyand's hernia represented 20\% of cases (eight cases). This high number very likely represents a publication bias where a rare event like a left Amyand's hernia is more likely to be published.

In most of the cases a normal appendix was described, but some authors reported adherences to the inguinal sac. This seems to be a common characteristic specially in long standing hernias. Some authors defend that appendectomy should be mandatory in these cases as dissection of these fibrous connections to allow appendiceal invagination may be laborious, incite more inflammation and lead to intra-abdominal (ex. appendicitis) or inguinal complications. ${ }^{14}$ The hernia sac content was also analysed: in nine clinical cases the vermiform appendix and the cecum were part of the hernia sac and in two cases the appendix was accompanied by a small bowel loop. In all cases the bowel was all perfectly viable.

Amyand's hernia is three times more common in children than it is on adults, something that is normally explained with the presence of a patent processus vaginalis. ${ }^{17}$ It is believed that the normal descend of the testicle through the inguinal canal can pull/drag the appendix, especially in the context of a patent processus vaginalis. This is supported by evidence of fibrous connection linking the appendix to the ipsilateral testicle in a case of Amyand's hernia ${ }^{18}$ and the fact that the large majority of cases are on male patients. In our samples this happens in 100\% of the reported cases. The congenital origin theory of Amyand's hernia is also supported by clinical reports of Amyand's hernia in newborns and premature babies. ${ }^{19}$ Patients can be completely asymptomatic through all their life. 
The diagnosis of inguinal hernia is clinical, and no imaging studies are generally required. Thus, Amyand's hernia diagnosis is mainly intraoperative and the preoperative diagnosis is uncommon. Five patients in this review had preoperative imaging exams before their surgeries, namely two had an inguinal ultrasound (US) in three an inguinal computer tomography (CT) scan. The exams were diagnostic in one patient who had the ultrasound and two who had the CT scan. Kinoo et al preoperatively diagnosed a left type IV Amyand's hernia by contrast enema study. ${ }^{20}$ It is not clear in the literature if a diagnosis before the surgery, though cross-sectional imaging will change the treatment decisions or not, although some authors claim this is the case. ${ }^{21}$

In this review of clinical cases, Amyand's Hernia is reported mostly on open inguinal hernia repairs. At least one case series describes three cases of transabdominal preperitoneal hernioplasty (TAPP). In all cases appendix looked mildly congested without gross evidence of inflammation, so no appendectomy was done. ${ }^{22}$ The authors argue that hernia repair with mesh should be the main goal and that latter appendectomy can always be addressed laparoscopically again. The first case of Amyand's hernia with inflamed appendix that was repaired laparoscopically was reported in 1999.23

\section{CONCLUSION}

Amyand's hernia is a rare finding, probably with congenital origin. Even though prophylactic appendectomy is not recommended in the presence of a normal appendix, most of the surgeons in the published clinical cases gathered in this study opted to do so. The absence of evidence-based information and the very low risk associated with appendectomy in this context may explain this option. The final decision to "cut or not to cut" the vermiform appendix in these setting is always surgeon-dependent, and should preferably balance patient characteristics (age, life-risk of appendicitis), hernia characteristics (size of defect, need for appendix dissection, anatomy of the appendix) and risk of hernia recurrence.

CONFLICTS OF INTEREST: The authors have no conflicts of interest to declare.

FINANCIAL SUPPORT: This work has not received any contribution grant or scholarship.

PROVENANCE AND PEER REVIEW: Not commissioned; externally peer reviewed.

CONFLITOS DE INTERESSE: Os autores declaram não possuir conflitos de interesse.

SUPORTE FINANCEIRO: O presente trabalho não foi suportado por nenhum subsídio ou bolsa.

PROVENIÊNCIA E REVISÃO POR PARES: Não comissionado; revisão externa por pares.

\section{REFERENCES}

1. Amyand C. Of an inguinal rupture, with a pin in the appendix caeci incrusted with stone; and some observations on wounds in the guts. Philos Trans R Soc Lond. 1736; 39: 329-42.

2. Ryan W. Hernia of the vermiform appendix. Ann Surg. 1937; 106:135-9.

3. Michalinos A, Moris D, Vernadakis S. Amyand's hernia: a review. Am J Surg. 2014;207:989-95. doi: 10.1016/j.amjsurg.2013.07.043.

4. Willson TD, Rao V, Podbielski FJ, Blecha MJ. In situ aortic thrombosis secondary to intra-abdominal abscess. Am J Case Rep. 2012;13:149-52. doi: 10.12659/AJCR.883244.

5. Maizlin ZV, Mason AC, Brown C, Brown JA. CT findings of normal and inflamed appendix in groin hernia. Emerg Radiol. 2007; 14:97-100.

6. Osorio JK, Guzmán-Valdivia G. Ipsilateral Aymand's and Richter's hernia, complicated by necrosing fascitis. Hernia. 2006;10:443-6.

7. Logan MT, Nottingham JM. Amyand's hernia: a case report of an incarcerated and perforated appendix within an inguinal hernia and review of the literature. Am Surg. 2001;67:628-9.

8. Losanoff JE, Basson MD. Amyand hernia: a classification to improve management. Hernia. 2008;12:325-6. doi: 10.1007/ s10029-008-0331-y.

9. Singal R, Mittal A, Gupta A, Gupta S, Sahu P, Sekhon MS. An incarcerated appendix: report of three cases and a review of the literature. Hernia. 2012;16:91-7. doi: 10.1007/s10029010-0715-7.

10. Okur MH, Karaçay S, Uygun I, Topçu K, Öztürk H. Amyand's hernias in childhood (a report on 21 patients): a single-centre experience. Pediatr Surg Int. 2013;29:571-4. doi: 10.1007/ s00383-013-3274-z.

11. Psarras K, Lalountas M, Baltatzis M, Pavlidis E, Tsitlakidis A, Symeonidis $N$, et al. Amyand's hernia-a vermiform appendix presenting in an inguinal hernia: a case series. J Med Case Rep. 2011;5:463. doi: 10.1186/1752-1947-5-463.

12. Priego P, Lobo E, Moreno I, Sánchez-Picot S, Gil Olarte MA, Alonso N, et al. Acute appendicitis in an incarcerated crural hernia: analysis of our experience. Rev Esp Enferm Dig. 2005;97:707-15.

13. Gurer A, Ozdogan M, Ozlem N, Yildirim A, Kulacoglu H, Aydin R. Uncommon content in groin hernia sac. Hernia. 2006;10:152-5.

14. Kose E, Sisik A, Hasbahceci M. Mesh inguinal hernia repair and appendectomy in the treatment of amyand's herniawith non-inflamed appendices. Surg Res Pract. 2017;2017:7696385. doi: 10.1155/2017/7696385.

15. Singal R, Zaman M, Sharma BP. Unusual entities of appendix mimicking appendicitis clinically - emphasis on diagnosis and treatment. Maedica. 2017;12:23-9.

16. Reilly DJ, Macula B, Brandt C. Primary mesh repair of Amyand's hernia. ANZ J Surg. 2015;85:93-4. doi: 10.1111/ans.12437.

17. Cankorkmaz L, Ozer H, Guney C, Atalar MH, Arslan MS, Koyluoglu G. Amyand's hernia in the children: a single center experience. Surgery. 2010;147:140-3. doi: 10.1016/j. surg.2009.09.038.

18. Oguzkurt P, Kayaselçuk F, Oz S, Arda IS, Oguzkurt L. Sliding appendiceal inguinal hernia with a congenital fibrovascular band connecting the appendix vermiformis to the right testis. Hernia. 2001 Sep; 5(3):156-7.

19. Martins JL, Peterlini FL, Martins EC. Neonatal acute appendicitis: a strangulated appendix in an incarcerated inguinal hernia. Pediatr Surg Int. 2001;17:644-5.

20. Mewa Kinoo S, Aboobakar MR, Singh B. Amyand's Hernia: A Serendipitous Diagnosis. Case Rep Surg. 2013;2013:125095. doi: 10.1155/2013/125095.

21. Celik A, Ergün O, Ozbek SS, Dökümcü Z, Balik E. Sliding appendiceal inguinal hernia: preoperative sonographic diagnosis. J Clin Ultrasound. 2003;31:156-8.

22. Sahu D, Swain S, Wani M, Reddy PK. Amyand's hernia: Our experience in the laparoscopic era. J Minim Access Surg. 2015;11:151-3. doi: 10.4103/0972-9941.147368.

23. Vermillion J, Aberntathy S, Snyder S. Laparoscopic reduction of Amyand's hernia. Hernia. 1999; 3:159-60. 